ORIGINAL ARTICLE

\title{
Digital Photo Analysis as a Predictor of Physiological Vertical Dimension
}

\author{
Andy Wirahadikusumah, Henni Koesmaningati, Sitti Fardaniah
}

Department of Prosthodontic, Faculty of Dentistry, Universitas Indonesia, Jakarta 10430, Indonesia

Corresponding e-mail to: henni.koesmaningati@gmail.com

\begin{abstract}
Determination of the vertical dimension is based on patient's resting jaw position, which is the physiological vertical dimension. Objective: To examine the accuracy of physiological vertical dimension using digital photography. Methods: The research was done on 64 students who meet the criterias. The measurements of eyes-lips angles and lower nose-chin distance was performed. Then photo shoot of subject faces was taken from $56 \mathrm{~cm}$ distance between the camera lens and the tip of the subjects' nose with tripoded camera. Results: Distance of eyes-lips angles, and lower the nose-chin of the face and the photo has no meaningful differences. Conclusions: Analysis of digital photos can be applied to predict physiological vertical dimension.
\end{abstract}

\begin{abstract}
ABSTRAK
Analisis foto digital untuk memprediksi dimensi vertikal fisiologis. Penetapan dimensi vertical (DV) diperoleh berdasarkan DV pada saat posisi istirahat rahang pasien yaitu dimensi vertikal fisiologis (DVF). Tujuan: Meneliti keakuratan pengukuran DVF dengan menggunakan foto digital. Metode: Penelitian dilakukan pada 64 mahasiswa yang memenuhi kriteria. Kemudian dilakukan pengukuran jarak sudut mata-sudut bibir dan jarak dasar hidung-ujung dagu pada wajah subjek. Lalu dilakukan pemotretan wajah subjek penelitian dengan ketentuan jarak $56 \mathrm{~cm}$ antara lensa kamera dengan ujung hidung subjek dengan kamera di atas tripod. Hasil: Jarak sudut mata-komisura bibir kanan dan kiri wajah, dan jarak dasar hidung-ujung dagu pada wajah dan foto tidak memiliki perbedaan bermakna. Simpulan: Analisis foto digital dapat diterapkan untuk memprediksi DVF.
\end{abstract}

Key words: digital photography, physiologic vertical dimension

\section{PENDAHULUAN}

Salah satu akibat kehilangan gigi adalah adanya perubahan dimensi vertical (DV). Penetapan DV diperoleh berdasarkan DV pada saat posisi istirahat rahang pasien yaitu dimensi vertikal fisiologis (DVF) dan saat beroklusi yaitu dimensi vertikal oklusi (DVO). Adanya perubahan DV dengan sendirinya akan memengaruhi relasi rahang sehingga menyebabkan gangguan dalam fungsi mastikasi, fonetik, dan penampilan. ${ }^{1}$ Keberhasilan suatu gigi tiruan tergantung pada ketepatan penentuan DV selama prosedur pembuatan. ${ }^{2}$ Oleh karena itu, penentuan dimensi vertikal (DV) merupakan suatu tahap penting yang menentukan keberhasilan perawatan gigi tiruan lepasan karena dapat mempengaruhi fonetik maupun fungsional.
Terdapat bermacam-macam metode penetapan hubungan rahang atau pengukuran DV. Banyaknya metode dan alat pengukuran wajah untuk mengukur DV membuat pilihan dokter gigi lebih bervariasi. Pengukuran DV secara tidak langsung adalah dengan media foto. Foto dapat berupa foto sefalo, foto lama pasien, dan foto digital wajah pasien. Foto digital sekarang ini dinyatakan merupakan representasi yang baik, dan secara signifikan lebih akurat daripada analisis sefalometri ketika pengukuran pada jaringan lunak dibutuhkan. ${ }^{3}$ Perbedaan angulasi dari alat ukur (terutama pada pasien dengan profil cembung, berkumis atau berjanggut, berleher pendek, bibir tebal) dan penekanan yang berbeda dari jaringan lunak di bawah dagu dan dasar hidung dapat menyebabkan kesalahan pengukuran. ${ }^{4}$ Alat ukur ini juga dapat mencederai pasien jika berkontak dengan 
kulit pasien, seperti jangka sorong. Pengukuran DVF pada foto digital akan menghilangkan kekurangan pengukuran pada wajah tersebut, namun keakuratannya masih dipertanyakan. Pengukuran DVF pada subjek mahasiswa di Brazil dengan menggunakan foto digital. Mereka menemukan bahwa pengukuran dimensi vertikal fisiologis wajah dapat dilakukan pada foto wajah secara digital. ${ }^{3}$ Dinyatakan bahwa jarak dari sudut mata (M) ke sudut bibir (B) adalah sama dengan jarak dari dasar hidung (DH) ke ujung dagu (UD). Walaupun penelitian ini sudah dilakukan di Brazil, namun hasilnya belum tentu sama di Indonesia. Hal ini dapat disebabkan oleh perbedaan ukuran dan bentuk kepala. ${ }^{5}$

\section{DV dan pembuatan gigi tiruan}

Definisi DV berdasarkan The Glossary of Prosthodontics Terms adalah jarak antara 2 titik anatomis (biasanya satu pada ujung hidung dan satu lagi pada dagu), satu pada jaringan tidak bergerak dan satu lagi pada jaringan bergerak). DVF adalah jarak antara 2 titik (satu di bagian tengah wajah atau hidung, dan satu lagi pada bagian bawah wajah atau dagu) diukur ketika mandibula dalam posisi istirahat fisiologis. ${ }^{6}$ Posisi istirahat fisiologis diartikan posisi rahang bawah saat otot elevator dan depressor dalam keadaan istirahat/fisiologis, tonus seimbang, dan kondilus dalam kedudukan rileks dalam fosa glenoid. ${ }^{7}$ Dimensi Vertikal Okulsi (DVO) adalah jarak antara 2 titik ketika kontak oklusi. ${ }^{6}$ Sampai saat ini belum ada metode yang dapat menghasilkan prediksi DVF paling tepat, padahal DVF yang tepat sangat penting dalam menciptakan oklusi yang baik. ${ }^{8}$

\section{Pengukuran DVO}

Ada beberapa cara untuk mengukur atau menentukan DVO antara lain secara langsung maupun tidak langsung. Pengukuran dengan cara langsung berarti pengukuran dilakukan langsung pada wajah atau mulut pasien. Yang termasuk dalam pengukuran DVO cara langsung adalah pengukuran wajah, swallowing (penelanan), metode fonetik, biting forces, metode taktil, dan rumus Hayakawa. Cara pengukuran DVF secara tidak langsung dapat dilakukan dengan menggunakan foto (foto sefalo, foto lama pasien, foto digital).

\section{Pengukuran wajah}

Pengukuran wajah dapat digunakan untuk mengukur DVO dari pasien yang tidak bergigi. Pengukuran ini umumnya dilakukan dengan alat ukur jangka sorong. Teknik pengukuran DVF bahwa jarak dari pupil mata ke sudut bibir adalah sama dengan jarak dari dasar hidung ke ujung dagu sering digunakan (Gambar 1). ${ }^{3}$ Metode McGee menghubungkan DVO dengan 3 pengukuran wajah yang dianggap konstan selama hidup, yaitu: jarak dari tengah pupil mata ke garis yang ditarik dari sudut bibir, jarak dari glabella ke subnasion, dan jarak antara sudut mulut ketika bibir istirahat. Metode McGee menyatakan dua dari tiga pengukuran ini akan sama dan terkadang ketiganya akan sama satu sama lain. Metode pengukuran yang dikembangkan oleh Hurst berdasarkan tinggi bibir atas dan bagian gigi insisivus sentral yang kelihatan ketika bibir terbuka dalam posisi istirahat. Metode ini membagi tipe bibir dari sangat pendek sampai sangat panjang, dan kemudian membuat tabel untuk menentukan DVO pada pasien tak bergigi. ${ }^{9}$ Metode pengukuran DVF pada wajah yang pernah diteliti, adalah dengan mengukur lebar mata yang dikatakan mempunyai nilai sama dengan jarak dasar hidung ke tepi bawah bibir. Pengukuran ini hanya berlaku pada kelompok wajah euryprosop, wajah rata-rata dan leptoprosop. Metode ini dikembangkan Hamm berdasarkan teori "eye unit" dan berdasarkan morfologi indeks wajah. ${ }^{10}$ Metode yang sering digunakan di klinik adalah metode 2 titik. Pasien dengan posisi kepala tegak dan rileks di kursi dental ditetapkan 2 titik pengukuran pada garis tengah wajah. Satu pada hidung, satu lagi pada dagu. Titik ini dipilih pada daerah yang tidak mudah bergerak akibat otot ekspresi. ${ }^{7}$ Alat yang digunakan pada pengukuran DVF secara langsung pada wajah bermacammacam. Untuk mengukur dimensi vertikal fisiologis (DVF) digunakan Sorensen Profile Scale. ${ }^{8}$ Telah dilakukan modifikasi alat ukur DV konvensional dan diberi nama TOM Gauge. ${ }^{11}$ Alat yang digunakan pada metode pengukuran 2 titik adalah jangka sorong dan Willis bite gauge.

\section{Pengukuran DVF dengan foto digital}

Pengukuran DVF menggunakan foto dapat dilakukan

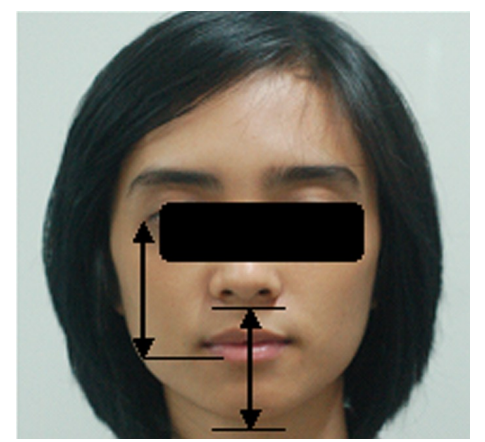

Gambar 1. Metode Willis, jarak sudut mata ke komisura bibir $=$ jarak dasar hidung ke ujung dagu. ${ }^{3}$ 
pada foto radiografi (foto sefalo), foto lama wajah pasien, dan foto digital. Foto tersebut diambil pada saat pasien dalam posisi istirahat fisiologis. Foto sefalo dapat digunakan sebagai data penunjang untuk perawatan terutama pada bagian sepertiga bawah wajah. Penelitian ini didukung oleh penelitian yang menyatakan bahwa foto sefalo dapat memberikan data ukuran DV, kondisi skeletal dan proporsi wajah pada pasien tak bergigi. ${ }^{12}$ Analisis sefalometri di lain pihak memberikan hasil yang kurang memuaskan dalam diagnosis dan perencanaan perawatan, sehingga praktisi dental masih bergantung pada evaluasi klinis. ${ }^{3}$ Masalah yang dihadapi adalah menentukan DVF, dan pembesaran gambar foto yang menimbulkan distorsi diperlukan catatan sebelum pencabutan. ${ }^{13}$ Bila tidak ada, dianjurkan untuk menggunakan foto lama dari pasien dan membandingkan jarak interpupil dan jarak alis ke dagu dari foto lama tersebut dengan kondisi pasien pada saat pemeriksaan. ${ }^{14}$

Saat ini mulai dikembangkan pengukuran tubuh manusia melalui foto 2 dimensi dan penindai 3 dimensi. Foto wajah merupakan representasi yang baik dari tampilan klinis karena lebih akurat dibanding analisis sefalometri ketika pengukuran jaringan lunak dibutuhkan. Ketebalan, panjang, dan tonus otot wajah bervariasi, sehingga kurang tepat untuk mengevaluasi jaringan ini dengan pemeriksaan radiografis. Banyak ahli bedah plastik justru bekerja berdasarkan foto wajah daripada radiografis. ${ }^{3}$ Adanya kemajuan teknologi yang pesat, pada zaman ini memungkinkan pengiriman data seperti foto wajah melalui internet, maka data pengukuran melalui foto wajah secara digital dapat diperoleh dengan cepat. Media foto sendiri sudah tidak asing lagi di dunia kedokteran khususnya kedokteran gigi. Banyak penelitian yang sudah menggunakan foto digital sebagai pembanding dan alat ukur, khususnya jika berhubungan dengan wajah. Telah diteliti proporsi golden ratio wajah dengan melakukan pengukuran pada foto digital. ${ }^{5,15}$ Efek peningkatan DV pada estetik wajah dengan menggunakan foto sebelum dan sesudah perawatan sebagai alat media penilaian efek tersebut. ${ }^{16}$ Pengukuran DVF dengan subjek mahasiswa di Brazil pada foto digital, dengan mengukur jarak sudut mata ke sudut bibir dan jarak dasar hidung ke ujung dagu menggunakan software HL image ++97 , ke dua jarak ini dinyatakan sama besarnya (Gambar 2). ${ }^{3}$ Ditemukan bahwa pengukuran dimensi vertikal fisiologis wajah dapat dilakukan pada foto wajah secara digital, menggunakan kamera foto digital dengan jarak pemotretan $56 \mathrm{~cm}$ antara ujung hidung subjek dengan lensa kamera, dengan ketinggian $112 \mathrm{~cm}$ pada tripod. Tripod digunakan dengan tujuan agak tidak terjadi pergerakan pada saat pemotretan sehingga dapat menyebabkan distorsi. Posisi subjek adalah duduk tegak menghadap kamera, dengan posisi rahang dalam posisi DVF. ${ }^{3}$

\section{METODE}

Penelitian dilakukan di RSGMP FKG Universitas Indonesia, pada mahasiswa/i FKG UI dengan kriteria sebagai mahasiswa/i FKG UI usia 20-35 tahun, tidak sedang dalam perawatan ortodontik, tidak memakai gigi tiruan lepasan/cekat, tidak ada kelainan/ pembedahan pada wajah yang dapat menyebabkan keasimetrisan, dan hubungan rahang kelas I. Alat dan bahan penelitian berupa formulir informed consent, Boley gauge dan Willis Bite gauge, kamera Nikon D50 DSLR (lensa 50mm) dan tripod, komputer dengan software Adobe Photoshop versi CS2, software SPSS 17.0 for Window, penggaris skala, spidol hitam, formulir data pasien. Pemberian instruksi dilakukan secara lisan dan tertulis kepada subjek penelitian, lalu subyrk menandatangani formulir informed consent. Kemudian dilakukan pengukuran jarak sudut mata-sudut bibir pada wajah subjek (sebelah kiri dan kanan). Setelah itu dilakukan pengukuran jarak dasar hidung-ujung dagu pada wajah subjek. Lalu dilakukan pemotretan wajah subjek penelitian dengan ketentuan jarak $56 \mathrm{~cm}$ antara lensa kamera dengan ujung hidung subjek, kamera diatas tripod. Subjek dalam posisi duduk dan melihat ke depan, kepala tegak, posisi rahang dalam keadaan istirahat/posisi DVF, garis tengah wajah tegak lurus garis interpupil. Pengukuran jarak sudut mata ke sudut bibir dan jarak dasar hidung ke ujung dagu pada foto (melalui software Adobe Photoshop CS2 pada komputer). Kemudian analisis hasil pengukuran melalui SPSS 17.0 for Windows.

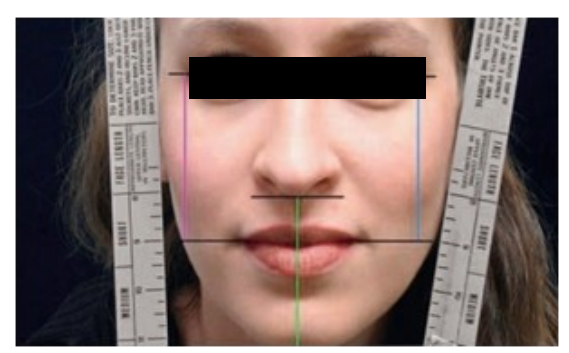

Gambar 2. Penelitian Pengukuran DVF dapat dilakukan pada foto digital ${ }^{3}$ 

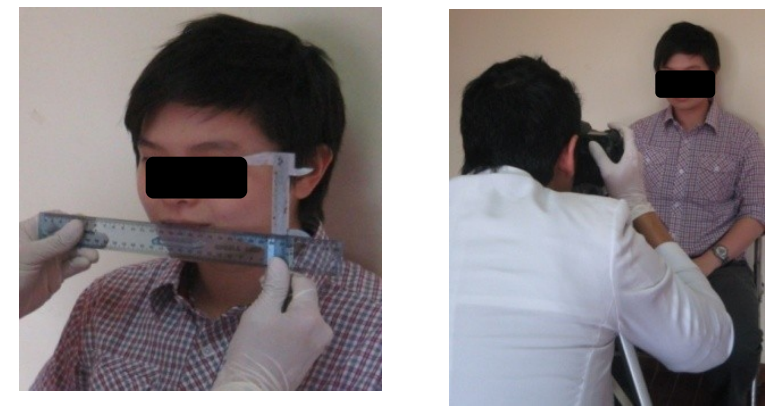

Gambar 3. Pengukuran DVF langsung pada wajah subjek, setelah itu dilakukan pemotretan dengan jarak yang ditetapkan

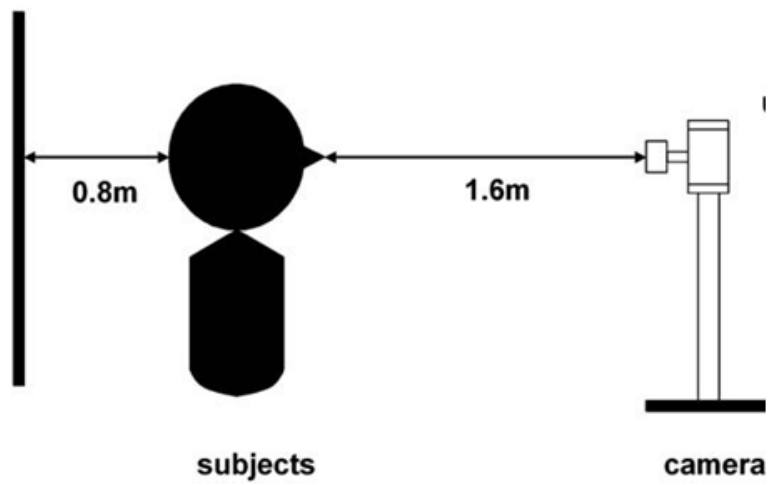

Gambar 4. Skema jarak pemotretan

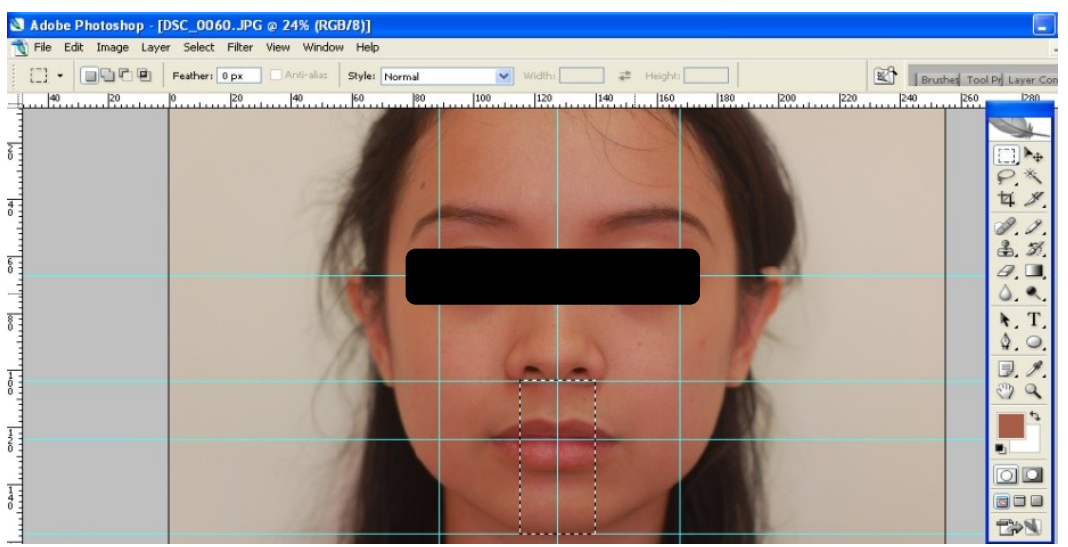

Gambar 5. Pengukuran sudut mata-komisura bibir dan jarak dasar hidung-ujung dagu pada foto digital melalui program Adobe photoshop

\section{HASIL}

Penelitian pada subjek sebanyak 64 mahasiswa yang memenuhi kriteria inklusi sebagai subjek penelitian, dengan rentang usia 20-35 tahun. Penelitian tentang pengukuran DVF pada wajah dengan menggunakan pengukuran jarak sudut mata ke sudut bibir dan dasar hidung ke ujung dagu belum pernah dilakukan di Indonesia. Oleh karena itu ditetapkan dilakukan penelitian pendahuluan pada 30 subjek terlebih dahulu, untuk mencari nilai simpang baku gabungan. Pada subjek penelitian dengan posisi istirahat fisiologis, dilakukan pengukuran jarak sudut mata ke komisura bibir sebelah kiri dan kanan wajah (LM-B dan RM-B) dan dasar hidung ke ujung dagu (DHUD) atau dapat disebut sebagai DVF. Setelah itu subjek penelitian difoto dengan jarak $56 \mathrm{~cm}$ antara ujung hidung ke lensa kamera. Hasil foto kemudian dilakukan pengukuran pada komputer sama dengan wajah yaitu sudut mata ke komisura bibir kiri dan kanan (LM-B foto dan RM-B foto) dan dasar hidung ke ujung dagu (DH-UD foto). Selanjutnya dilakukan penghitungan angka rerata dan simpang baku baik pengukuran pada wajah maupun pada foto. Data ini kemudian dimasukkan ke dalam rumus besar subjek penelitian untuk penelitian analitik numerik tidak 
berpasangan, sehingga didapatkan besar subjek penelitian sebesar 64 orang. Hasil pengukuran pada wajah dan foto kemudian dilakukan uji normalitas dan uji varians, karena ini adalah syarat mutlak sebelum dilakukan uji one way Anova. Hasil uji normalitas Kolmogorov-Smirnov pengukuran DV pada wajah ternyata menghasilkan angka $p=0,2$ pada ketiga variabel pengukuran wajah, ini berarti variabel pengukuran wajah mempunyai distribusi normal $(p>0,05)$. Dari uji normalitas $(0,2)$ dan uji varians $(0,507)$ pada wajah, didapatkan bahwa keduanya mempunyai $p>0,05$ sehingga dapat dilakukan uji one way Anova. Uji one way Anova didapatkan hasil $p>0,05 \quad(0,448)$, sehingga didapatkan kesimpulan bahwa ketiga titik referensi yaitu jarak sudut mata ke komisura bibir bagian kanan wajah (RM-B), jarak sudut mata ke komisura bibir bagian kiri wajah (LBM) dan jarak dasar hidung ke ujung dagu (DH-UD) pada wajah tidak memiliki perbedaan bermakna atau dengan kata lain adalah sama (Tabel 1). Pengukuran DVF pada foto digital didapatkan uji normalitas $p<0,05(0,018)$, sehingga dilakukan transformasi data dan dilakukan uji normalitas kembali. Didapatkan hasil uji Kolmogorov-Smirnov adalah normal atau $p>0,05$. Uji varians pengukuran DVF pada foto digital juga didapatkan $p>0,05(0,837)$ atau dengan kata lain varians data variabel DVF pada foto digital adalah sama.

Uji One way Anova dapat dilakukan pada variabel pengukuran DVF pada foto digital, karena 2 syaratnya telah terpenuhi yaitu uji normalitas dan uji varians adalah normal $(p>0,05)$. Melalui uji one way Anova didapatkan bahwa $p>0,05(0,28)$, sehingga didapatkan kesimpulan bahwa ketiga titik referensi yaitu jarak sudut mata-komisura bibir bagian kanan wajah (RM-B), jarak sudut mata-komisura bibir

Tabel 1. Hasil uji one way Anova pengukuran DVF pada wajah

\begin{tabular}{llllc}
\hline & & $\mathrm{n}$ & Rerata \pm s.b & $p$ \\
\hline Pengukuran & RM-B (Kanan) & 64 & $67,82 \pm 3,77$ & 0,448 \\
pada wajah & LM-B (Kiri) & 64 & $67,97 \pm 3,66$ & \\
& DH-UD & 64 & $67,16 \pm 4,11$ & \\
\hline
\end{tabular}

Tabel 2. Hasil uji one way Anova pengukuran DVF pada foto digital

\begin{tabular}{llccc}
\hline & & $\mathrm{n}$ & Rerata \pm s.b & $p$ \\
\hline Pengukuran & RM-B (kanan) & 64 & $54,21 \pm 6,53$ & 0,28 \\
pada foto & LM-B (kiri) & 64 & $54,21 \pm 6,40$ & \\
digital & DH-UD & 64 & $52,69 \pm 6,41$ & \\
\hline
\end{tabular}

Tabel 3. Hasil uji korelasi Pearson antar variabel pengukuran DVF wajah \& foto digital

\begin{tabular}{lcc}
\hline & & Pengukuran DVF pada foto digital \\
\hline Pengukuran DVF & $\mathrm{r}$ & 0,425 \\
pada wajah & $p$ & 0,000 \\
& $\mathrm{n}$ & 192 \\
& & \\
\hline
\end{tabular}

bagian kiri wajah (LB-M) dan jarak dasar hidungujung dagu (DH-UD) pada foto tidak memiliki perbedaan bermakna atau dengan kata lain adalah sama. (Tabel 2). Berikutnya akan diuji apakah ada korelasi antara pengukuran DVF pada wajah dan foto digital.

Uji korelasi dilakukan dengan uji korelasi Pearson. Uji ini dipilih karena kedua variabel memenuhi syarat sebagai variabel numerik tidak berpasangan dengan $>2$ kelompok, serta memiliki distribusi data yang normal. Uji korelasi Pearson antar variabel pengukuran DVF pada wajah dan foto digital menghasilkan nilai $p$ sebesar 0,00 yang berarti terdapat korelasi yang bermakna dan nilai $r$ sebesar 0,425 yang berarti kekuatan korelasinya sedang (Tabel 3).

\section{PEMBAHASAN}

Pada penelitian ini jenis kelamin tidak diperhatikan, tetapi mengingat populasi mahasiswa FKG UI sebagian besar adalah wanita maka subjek pada penelitian ini yang berjenis kelamin wanita adalah sebanyak 48 orang, sedangkan pria hanya 16 orang dari total jumlah 64 orang subjek. Rentang usia subjek penelitian adalah 20-35 tahun, dengan asumsi belum kehilangan banyak gigi pada rentang usia tersebut yang dapat menyebabkan terjadi perubahan DVF. Pada usia tersebut, pertumbuhan dan perkembangan juga diasumsikan sudah maksimal, karena pertumbuhan mata mencapai tahap sempurna pada usia 10 tahun. Pada usia 12-25 tahun terjadi pemanjangan lebar mata sebesar $10 \%$ dan kemudian pada usia 35-85 tahun akan terjadi hal sebaliknya yaitu pengurangan lebar mata yang kurang lebih besarnya sama. ${ }^{17}$

Pada penelitian ini, kondisi subjek yang sedang dalam perawatan ortodonti, menggunakan gigi tiruan baik lepasan atau cekat, adanya asimetris pada wajah akibat trauma atau operasi, tidak boleh dijadikan subjek penelitian. Kriteria ini diberlakukan untuk menghindari kesulitan pengukuran DVF, yang dapat mengakibatkan ketidakakuratan hasil pengukuran. Adanya kawat ortodonti, tambalan besar, gigi tiruan sebagian dikhawatirkan akan menyebabkan DV berubah karena adanya prematur kontak atau berubahnya relasi rahang. Asimetris wajah akibat trauma atau operasi terutama pada daerah sudut mata dan bibir akan menyulitkan pengukuran, sehingga dapat mengakibatkan kesalahan pengukuran.

Pengambilan foto digital wajah dan pengukuran dilakukan pada subjek dengan posisi kepala tegak dan posisi rahang istirahat. Seperti kita ketahui faktorfaktor yang mempengaruhi DV dalam jangka pendek meliputi posisi kepala, kehilangan gigi, rasa sakit di daerah mulut (berkaitan dengan otot) dan faktor pernafasan. Faktor yang bersifat jangka panjang 
meliputi usia, kesehatan umum, dan kebiasaan prafungsi yang dapat mengakibatkan abnormalitas oklusi sehingga sangat berhubungan dengan hipertonus otot yang mempengaruhi DVF. Posisi kepala ke arah belakang akan memperbesar DVF, sedangkan posisi kepala yang sedikit menunduk memperkecil DVF. Posisi kepala yang dianjurkan pada saat penentuan DV, pasien harus dalam keadaan relax, dengan bidang Frankfurt sejajar lantai. ${ }^{18}$ Posisi ini adalah sama persis dengan posisi standar bahwa bidang Frankfurt harus sejajar dengan bidang horisontal foto dengan pasien melihat ke depan, posisi relaks, sambil mengkatupkan rahangnya serta bibir dengan ringan. Garis yang ditarik antar titik orbital juga harus sejajar dengan bidang horisontal foto. ${ }^{19}$ Program HL Image ++97 mengukur jarak sudut mata-komisura bibir dan jarak dasar hidung ke ujung dagu pada hasil foto digital wajah, namun karena software program itu sulit dicari dan jarang digunakan di Indonesia, maka peneliti mencari alternatif program lain yang dapat menggantikan program tersebut dan mempunyai fungsi yang dapat mengukur foto digital wajah dengan akurat. ${ }^{3}$ Peneliti menggunakan program yang umum dipakai, murah, dan mudah digunakan yaitu Adobe Photoshop. Program ini umumnya digunakan untuk mengedit foto, namun ternyata peneliti menemukan bahwa program ini juga efektif untuk mengukur titik-titik tertentu pada foto digital wajah. Aplikasi klinik hasil penelitian ini adalah memungkinkan pengukuran DVF dilakukan pada foto digital wajah yang diambil dokter gigi pada saat kunjungan pertama pasien. Dalam jangka panjang adalah mungkin nantinya pengukuran DVF dapat dilakukan dengan pasien mengirimkan foto wajahnya, walaupun ini masih berupa harapan peneliti yang masih harus diteliti lebih lanjut. Salah satu alasan adalah perbandingan foto dengan wajah belum didapatkan melalui penelitian ini, Namun peneliti yakin itu tidak sulit didapatkan, terlebih jika sudah ada program yang mengubah ukuran foto ke ukuran sebenarnya. Dengan adanya korelasi antara pengukuran DVF secara langsung pada wajah dan tidak langsung pada hasil foto digital, tidak tertutup kemungkinan metode pengukuran DVF wajah yang lain dapat juga dilakukan pada foto digital wajah.

Kelemahan penelitian ini adalah belum secara khusus mengategorikan hasil pengukuran berdasarkan ras, jenis kelamin dan bentuk wajah. Selain itu, karena tidak adanya tempat atau studio khusus sehingga peneliti harus berpindah tempat untuk pemotretan wajah subjek, dikhawatirkan terjadi perbedaan hasil foto yang mungkin disebabkan perbedaan cahaya dan jarak. Lebih baik disediakan tempat khusus jika pemotretan sering dilakukan di tempat praktik dokter gigi, dapat juga dengan menandai tempat pasien dan kamera di lantai untuk memastikan hasil foto yang sama. ${ }^{19}$

\section{SIMPULAN}

Pengukuran jarak sudut mata ke sudut bibir dan jarak dasar hidung ke ujung dagu dapat dilakukan secara langsung pada wajah dan secara tidak langsung pada foto digital. Terdapat korelasi yang bermakna antara pengukuran pada wajah dan pada foto digital, sehingga analisis foto digital dapat diterapkan untuk memprediksi DVF. Diperlukan penelitian lebih lanjut dengan memperhatikan bentuk wajah, jenis kelamin dan kategori usia yang berbeda. Perlu diteliti lebih dalam korelasi antara perbandingan pengukuran DVF di wajah dan di foto digital sehingga penerapannya diharapkan dapat lebih akurat. Dalam penelitian selanjutnya diharapkan adanya tempat atau studio khusus, dengan cahaya dan jarak tidak berubah, sehingga hasil foto tidak distorsi dan terjaga kesamaannya.

\section{DAFTAR PUSTAKA}

1. Sharry JJ. Complete denture prosthodontic. 3rd ed. New York. McGraw-Hill Book. 1974.

2. Mehta JD, Joglekar AP. Vertical jaw relation as a factor in partial dentures. J Prosth Denti. 1969;21:618-25.

3. Gomes VL, et al. Vertical dimension of the face analyzed by digital photographs. Euro J Esth Dent. 2008;3:362-70.

4. Basker RM.,Davenport JC. Prosthetic treatment of edentulous patient. Blackwell Munksgaard. Copenhagen. 2002.

5. Mizumoto Y, Deguchi ST, Fong KWC. Assessment of facial golden proportions among young japanese women. American J Orthodon Dentofac Orthop. 2009;136:168-73.

6. The Academy of Prosthodontics. The glossary of prosthodontics terms. J Prosth Dent. 2005;94:5780.

7. McCord JF, Grant AA. Registration: Stage IIintermaxillary relations. Brit Dent J. 2000;188:601-7.

8. Toolson LB, Smith DE. Clinical measurement and evaluation of vertical dimension. J Prosthet Dent. 2006:95:335-9.

9. Turrell AJW. Clinical assessment of vertical dimension. J Prosth Dent. 2006;96:79-82.

10. Khatalia A, et al. Prediksi dimensi vertikal fisiologis menggunakan lebar mata, Tesis.FKGUI.2005.h.33. Indonesian.

11. Morikawa $\mathrm{M}$, et al. Reproductibility of the vertical dimension of occlusion with an improved measuring gauge. J Prosth Dent. 1988;60:56-61.

12. Souza RF, et al. Effect of denture fabrication and wear on closest speaking space and interocclusal distance during deglutition. J Prosth Dent. 2007;97:381-8. 
13. Bissasu M. Pre-extraction records for complete denture fabrication: A literature review. J. Prosthet Dent. 2004;91:55-8.

14. Fayz F, Eslami A. Determination of occlusal vertical dimension: A literature review. J Prosthet Dent. 1988;59:321-3.

15. Kiekens MAR, et al. Putative golden proportions as predictor of facial esthetics in adoslescents. American Orthodont Dentofac Orthop. 2008;134:480-3.

16. Mohindra NK, Bulman JS. The effects of new dentures on facial esthetics. Brit Dent J. 2002;192:164-8.

17. Van den Bosch WA, et al. Topographic anatomy of the eyelids, dan the effects of sex and age. Brit J Opthalmol.1999;83:347-52.

18. Geerts GA, Stuhlinger ME, Nel DG. A comparison of the accuracy of two methods used by pre-doctoral students to measure vertical dimension. J Prosth Dent. 2004;91:59-66.

19. Bengel W. Mastering dental photography. 1 st ed. Berlin:Quintessence.2002. 